Article

\title{
The Impact of Effective Microorganisms (EM) and Organic and Mineral Fertilizers on the Growth and Mycorrhizal Colonization of Fagus sylvatica and Quercus robur Seedlings in a Bare-Root Nursery Experiment
}

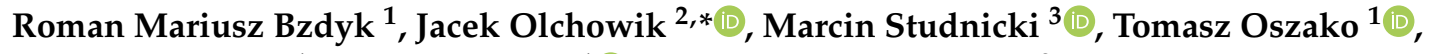 \\ Katarzyna Sikora ${ }^{1}$, Hanna Szmidla ${ }^{1}\left[\right.$ and Dorota Hilszczańska ${ }^{2}$ \\ 1 Department of Forest Protection, Forest Research Institute, Braci Leśnej 3, 05-090 Sękocin Stary, Poland; \\ romanbzdyk@gmail.com (R.M.B.); t.oszako@ibles.waw.pl (T.O.); K.Sikora@ibles.waw.pl (K.S.); \\ H.Szmidla@ibles.waw.pl (H.S.) \\ 2 Department of Forest Ecology, Forest Research Institute, Braci Leśnej 3, 05-090 Sękocin Stary, Poland; \\ D.Hilszczanska@ibles.waw.pl \\ 3 Department of Experimental Design and Bioinformatics, Faculty of Agriculture and Biology, Warsaw \\ University of Life Sciences, Nowoursynowska 159, 02-776 Warsaw, Poland; marcin_studnicki@sggw.pl \\ * Correspondence: olchowik.jacek@gmail.com; Tel.: +48-790-581-350
}

Received: 30 August 2018; Accepted: 24 September 2018; Published: 26 September 2018

check for updates

\begin{abstract}
Every year there are changes in the register of fungicides available for forestry. It is proactive to develop a new strategy to minimise the application of chemical methods and replace them with natural and biological fungal control options. This study compares the influence after one growing season in a bare-root forest nursery of (a) effective microorganisms (EM) consisting of mixed cultures of beneficial and naturally-occurring microorganisms, (b) the organic fertilizer Actifos (Act), and (c) the mineral fertilizer Busz Forte (BF) on the growth and mycorrhizal colonization of two common forest deciduous tree species: Fagus sylvatica and Quercus robur. None of the analysed growth parameters (root collar diameter, length of shoots and roots, dry mass of shoots, and roots) of either tested tree species differed significantly among treatments. For both tree species, seedlings treated with EM exhibited partnerships with a smaller species richness of mycorrhizae than did seedlings in other treatments. Moreover, EM treatment significantly increased the abundance of non-vital root tips for both species. By contrast, BF exerted a negative effect on F. sylvatica non-vital mycorrhiza abundance. Based on morphological and molecular identification, a total of 11 ectomycorrhizal (ECM) fungal taxa were detected in this study; three species (Peziza ostracoderma, Scleroderma areolatum and Cenococcum-like) were shared between both plant species. Across treatments, the most abundant ECM fungal species on F. sylvatica roots were Pezizaceae sp. (51.1\%) and Hebeloma sp. (38.1\%), while Peziza ostracoderma (26.8\%), Naucoria salicis (24.1\%), and Scleroderma areolatum (16.9\%) were the most abundant taxa on $Q$. robur seedling roots. Our data indicate a negative effect of EM on ectomycorrhizal colonisation and on species richness of ECM fungi associated with F. sylvatica and Q. robur seedlings. None of the tested products had a negative effect on seedling growth, but seedlings treated with EM were characterised by a significant higher abundance of non-vital mycorrhizae.
\end{abstract}

Keywords: ectomycorrhizae; oak; beech; EM; fertilization; forest nursery 


\section{Introduction}

In European forests, tree planting is a basic reforestation tool based on the principle of sustainability and contributing to the productivity of forests. Based on data from European countries in 2010, over half of the region's forests (53.2 million hectares) benefited from planting [1]. Globally, in 2012 , more than $46 \%$ of industrial roundwood originated from planted forests. In 2015, the global area of planted forest was estimated to be around 277.9 million ha, out of which 70.4 million ha are in Europe [2]. In Poland, reforestations of public, State and private forests in 2016 totalled 58,106 ha, of which 48,183 ha were artificially reforested. In the same year, a total of 1996 ha were in seedling production in nurseries of public and State Forests (PGL LP) [3]. Production of seedlings in PGL LP (State Forests) takes place in a field, container and tunnel system. Nearly $88 \%$ of total seedling output comes from bare-root nurseries. In 2016, a total of 759 million seedlings of forest trees and shrubs were produced in Poland's State Forests, of which almost half (48.9\%) were hardwood species [4].

English oak (Quercus robur L.) and European beech (Fagus sylvatica L.) are among the most economically and ecologically important deciduous tree species in Europe [5,6]. In Poland, deciduous tree stands occupy 31.5\% of forest area; oak and beech occupy $7.7 \%$ and 5.9\%, respectively [3]. The ectomycorrhizal (ECM) status of F. sylvatica and Q. robur is well documented [7]. Symbiotic relationships with ECM fungi are essential for the growth and vitality of these tree species in forest conditions. This is the case for both mature trees and seedlings, whether naturally regenerating or produced in nurseries [8-14]. Mycorrhizae played an important role in the successful colonization of land by plants [15], and these relationships are critical for plant nutrition and protection against abiotic and biotic factors [16,17]. The abundance and diversity of mycorrhizal fungi on seedling roots have a direct impact on the health of plants and adaptation of seedlings to planting on the plantations [18]. Moreover, some studies indicate that particular mycorrhizal fungi can be beneficial in nursery production: inoculation with a mixture of mycelium and spores from some ECM fungi improved plant growth and nutrition more than the application of nitrogen, phosphorus and potassium (NPK) fertilizer [19].

An important part of nursery and plantation management is the maintenance of adequate nutrient levels in growing seedlings. In forest nurseries, an essential source of soil nutrients is mineral fertilization with organic fertilizer applied periodically. In addition to the above-mentioned fertilization, nursery intensive production requires supplementary foliar fertilization [20]. Satisfactory nutrient levels will help to produce vigorous and healthy seedlings, supporting earlier establishment of the trees on plantations and decreased risk from abiotic and biotic factors including weed growth, drought, frost, and plant pathogens [21,22]. In addition to increasing tree growth, fertilization can be used for plant protection. Losses due to root diseases have been shown to be reduced by potassium fertilization, and application of nitrogen fertilizer reduced feeder root diseases caused by Phytophthora cinnamomi on shortleaf pine [23]. On the other hand, fertilization practices can also affect the establishment of ECM, as different fungal species can differ in their tolerance to different fertilization methods [24]. Various growth effects were shown to be influenced by both fertilization methods, and the fungal species used in inoculation [22]. Fertilizers may enhance mutualistic host-mycobiont associations [25] or inhibit mycorrhizal colonisation [18].

The harmful effects of fungal pathogens on seedlings produced in forest nurseries requires preventive measures (e.g., the use of appropriately selected fungicides). However, the use of chemical pesticides is limited in forestry by new EU regulation, and by the requirements of FSC and PEFC certification. Under these regulations, increasingly, the application of conventional plant protection products was discouraged in favour of green and environmentally friendly approaches. Since each year there are changes in the register of fungicides available for forestry, it is timely to develop a new strategy for integrated disease management (IDM) in nurseries, including good management practices (crop rotation, avoiding stress), and the use of natural protective agents (mycorrhizae, allelopathy, and other helping organisms). Such approaches may minimise the application of certain chemical methods. Additionally, most chemical and disease control treatments have a limited impact or negative 
effect on the growth of mycorrhizal fungi [26,27]. For this reason, it is generally accepted that their use should be limited to a minimum or replaced by biological protection, if possible.

A new tool, previously used in agriculture, is the use of the so-called effective microorganisms (EM) in forest nurseries [28]. EM consists of mixed cultures of beneficial and naturally-occurring microorganisms that can be applied in the nursery as inoculants to increase the microbial diversity of soils and plants. Research has shown that inoculation with EM cultures of the soil/plant ecosystem can improve soil quality as well as the health, growth, yield and quality of crops. EM contains particular taxa of microorganisms including populations of lactic acid bacteria, yeasts, and smaller numbers of photosynthetic bacteria, actinomycetes, and other types of organisms [29]. Producers of EM mixtures claim that their use allows for the cessation of traditional fertilization. In addition, other natural methods of plant protection are used in nurseries. For example, antibacterial, antifungal, and anti-oomycete activity of allicin, a phytochemical present in garlic, has been proven in planta [30,31]. Allicin effectively controlled seed-borne pathogens (Alternaria sp.) and Phytophthora leaf blight and tuber blight [31].

The aims of this study were to examine the effects of inorganic and organic fertilizer applications and their potential toxicities on ECM, as well as the use of EM (in place of fertilization) on plant productivity. For this purpose we examined the mycorrhizal communities associated with oak and beech seedlings after foliar applications of the following: EM, Actifos (Act), and Busz Forte (BF). The tested products have natural fungistatic and fertilization effects, and can be easily released into commercial use. Currently available information about the effects of EM on ECM symbioses is quite limited. This is of concern because proper growth, development, and survival of seedlings is strongly dependent on the presence of mycorrhizae. To the best of our best knowledge, this will be the first report about the effects of EM on ECM colonization of hardwood seedlings. We tested the hypothesis that EM will improve the growth and health status of tested oak and beech seedlings by contributing to increased and mycorrhizal colonization and diversity.

\section{Materials and Methods}

\subsection{Survey Area and Experimental Design}

This study was conducted in the bare-root forest nursery Żabieniec in the Chojnów Forest District (Mazovian Lowland, Central Poland, 52 $02^{\prime} 51.8^{\prime \prime}$ N 21 $04^{\prime} 51.7^{\prime \prime}$ E, 180 m.a.s.l). Climate data were obtained from the nearest meteorological station (Chojnów). Annual precipitation at the study site was $520 \mathrm{~mm}$; mean annual temperature is $9.3^{\circ} \mathrm{C}$. Average growing season length in the nursery is 210 days. The size of the forest nursery was about 9 ha, divided into several compartments with four to six standard nursery seedbeds in each. About $438 \times 10^{3}$ deciduous tree seedlings, such as (Quercus spp.), beech (Fagus sp.), birch (Betula spp.), sycamore (Acer pseudoplatanus), maple (Acer spp.), linden (Tilia spp.), alder (Alnus spp.) and elm (Ulmus spp.), are produced annually. Quercus robur and F. sylvatica seeds were selected and seeded mechanically, as well as fertilized following a schedule designed to satisfy their nutrient requirements, and based on soil analysis. Detailed information about nursery management (i.e., fungicide treatments, fertilization regimes, irrigation, etc.) are available at the nursery. Although such details may influence mycorrhizal condition, the purpose of this study was to determine the mycorrhizal status of planting stock, not the causes of the condition.

This study evaluated the effectiveness of foliar application of three different commercially available fertilizer treatments: (1) Actifos (which contains ammonium phosphite as a key component at $29.6 \%$, along with $10.2 \%$ nitrogen + microelements: $\mathrm{B}-0.02 \%, \mathrm{Cu}-0.008 \%, \mathrm{Fe}-0.06 \%, \mathrm{Mn}-0.04 \%$, $\mathrm{Mo}-0.004 \%, \mathrm{Zn}-0.02 \%$; and applied at a concentration of $0.6 \%$; manufacturer AGROPAK, Jaworzno, Poland), (2) the organic mineral fertilizer Busz Forte (comprising the so-called soap of potash as well as wormwood, garlic, nettle and algae extracts + microelements: $\mathrm{N}-3 \%, \mathrm{P}_{2} \mathrm{O}_{5}-3 \%$, $\mathrm{K}_{2} \mathrm{O}-2.5 \%$; containing an adjuvant; and applied at a concentration of $5 \%$; manufacturer Himal, Księstwo, Poland) and (3) the microbial product effective microorganisms (EM) (in a concentration 
of $10 \%$; EM Technology $\mathrm{T}^{\mathrm{TM}}$; manufacturer EMRO, Kishaba, Japan). EM is a commercial mixture of photosynthesizing bacteria, Actinomycetes, lactic acid bacteria, yeasts, and fermenting fungi (Aspergillus and Penicilium) [31]. The microbiological composition of the EM concentrate was as follows (the number of colony forming units per $\mathrm{mL}$ is provided in brackets): Streptomyces albus $\left(10^{5}\right)$, Propionibacterium freudenreichil $\left(10^{5}\right)$, Streptococcus lactis $\left(10^{5}\right)$, Aspergillus oryzae $\left(10^{5}\right)$, Mucor hiemalis $\left(10^{5}\right)$, Saccharomyces cerevisiae $\left(10^{5}\right)$, and Candida utilis $\left(10^{5}\right)$. EM also contains an unspecified amount of Lactobacillus sp., Rhodopseudomonas sp. and Streptomyces griseus [32].

The study used two randomized complete blocks for each of the two species. For each species there were 5 blocks with each of the four treatments (Control, Act, BF and EM) randomly assigned to one plot in each of the five blocks. Each plot was surrounded by a buffer zone-a green belt of land without any treatments (Figure 1). On 20 June and 4 July, 2013, 3-year-old seedlings of Q. robur and F. sylvatica were sprayed with $500 \mathrm{~L}$ of water containing the fertilizer treatment at a concentration of $100 \mathrm{~L} / \mathrm{ha}$. The fertilization was applied in the morning, in average overcast conditions and light wind, with temperature of approx. $20^{\circ} \mathrm{C}$. At the end of the growing season (25 October 2013), five beech seedlings and three oak seedlings were randomly selected per treatment from each block.

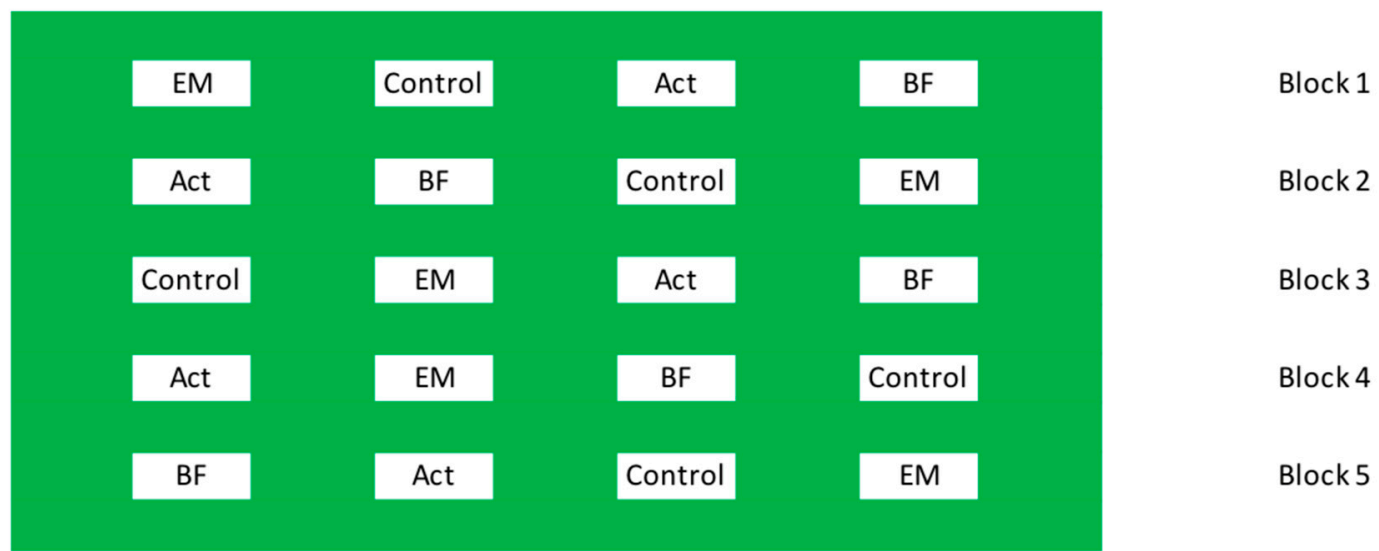

Buffor zone

Figure 1. The randomized complete block design.

\subsection{Growth Parameters and Ectomycorrhizal Assessment}

The roots were separated from the shoots of harvested plants and then rinsed under running tap water in a sieve. The following biometric parameters were measured: root collar diameter, height of shoot and root length. Total root length was determined using an Epson 10000-XL high-resolution scanner (Epson, Suwa, Japan) integrated with Whin-RHIZO Root Imaging Software (Regent Instruments Inc., Quebec City, QC, Canada). Using a scalpel, roots fragments ranging from 5 to $10 \mathrm{~cm}$ in length were cut out randomly and placed in a petri dish $(\varnothing 10 \mathrm{~cm})$ containing distilled water for microscopic analysis. An average of 250 root tips per seedling were analysed. The roots were analysed under a stereo microscope (Delta Optical IPOS-808, Warsaw, Poland), magnification of 10-40×, coupled with a digital camera. Fine roots were counted and the presence or absence of a hyphal mantle was recorded for non-vital (NV-a scurfy surface and an easily detachable cortex, with or without the remnants of an ECM mantle), vital non-mycorrhizal (NM-a well-developed, turgid tip, mantle lacking, root hairs present) and vital ectomycorrhizal (VM-as above, but with ECM fungal mantle and without root hairs) root tips according to Montecchio et al. [33]. Initial mycorrhizal identification was based on existing identification keys: ectomycorrhizal fungi were subjected to morphological classification according to a simplified scheme after Agerer [34] and Agerer and Rambold [35]. In the case of ramified morphotypes, each mycorrhizal root tip was counted separately. Each of the observed mycorrhizal morphotypes was documented photographically. To determinate the mycorrhizal taxa, tip material 
was collected from three to five mycorrhizal root tips per morphotype and transferred into Eppendorf tubes, labelled and stored frozen in $70 \% \mathrm{EtOH}$ at $-25^{\circ} \mathrm{C}$ for molecular analysis. Fungal species were determined based on the results of nuclear ribosomal of internal transcribed spacer (ITS) DNA (internal transcribed spacer) sequences. Thereafter, all morphotypes were re-labelled according to DNA-based identification. The abundance of vital ECM root tips (VM), calculated as vital ECM vital root tips/total number of root tips (which included vital ECM root tips (VM) + non-mycorrhizal root tips (NM) + non-vital $(\mathrm{NV})) \times 100$, was calculated and presented as a degree of mycorrhization. NM and NV were also expressed in percentages. The relative abundance of ECM morphotypes was expressed for each morphotype count as the percentage of all vital ECM root tips (VM). The mycorrhizal fungal species richness (n), indicating the number of molecularly confirmed ECM morphotypes, was calculated separately for each treatment within each block based on the sum from the five beeches and three oaks seedlings. The frequency of mycorrhizal taxa was expressed for each morphotype as the percentage of colonized plants. After an assessment of ECM colonisation, the root and shoot samples were dried at $105^{\circ} \mathrm{C}$ and the dry weights of roots and shoots were measured.

\subsection{Molecular Identification of Mycorrhizal Root Tips}

We amplified the ITS region of nuclear ribosomal DNA by direct PCR using the primers ITS1F/ITS4, and sequenced the product of the PCR reaction. The polymerase chain reaction (PCR) was performed using the Phire ${ }^{\circledR}$ Plant Direct PCR Kit (Thermo Scientific ${ }^{\circledR}$, Waltham, MA, USA) according to the manufacturer's protocol [36]. This direct PCR method bypasses DNA extraction. Subsamples of each ECM morphotype (fragments of ECM fungal mantles and emanating hyphae), stored in 70\% alcohol at $-20{ }^{\circ} \mathrm{C}$ were transferred into $0.2 \mu \mathrm{L}$ PCR tubes. Ethanol was allowed to evaporate by resting the tube with an open lid at $40{ }^{\circ} \mathrm{C}$ for $20 \mathrm{~min}$ before the PCR master mix was added. The PCR was performed in a volume of $20 \mu \mathrm{L}$ of a mixture containing: $1 \times$ PCR Buffer Phire ${ }^{\circledR}$ Plant; $0.4 \mu \mathrm{L}$ Hot Start II DNA polymerase; $0.5 \mu \mathrm{M}$ forward primer (ITS 1F); $0.5 \mu \mathrm{M}$ reverse primer (ITS 4) and $0.5 \mu \mathrm{L}$. Amplification reactions were performed in a PTC-200 ${ }^{\mathrm{TM}}$ Programmable Thermal Controller (MJ Research, Inc., Hercules, CA, USA) thermocycler according to the protocol developed in the Laboratory of Molecular Biology, Forest Research Institute (IBL), Poland. This protocol consisted of: 5 min of initial denaturation of the DNA matrix at $98^{\circ} \mathrm{C}$, followed by 40 cycles of amplification (where each cycle included denaturation for $5 \mathrm{~s}$ at $98^{\circ} \mathrm{C}$; primer annealing for $25 \mathrm{~s}$ at $60^{\circ} \mathrm{C}$; product elongation for $1 \mathrm{~min}$ at $72{ }^{\circ} \mathrm{C}$ ), and culminating in elongation of PCR products for $1 \mathrm{~min}$ at $72{ }^{\circ} \mathrm{C}$ ). PCR products were assessed by electrophoresis in $1 \%$ agarose gel stained with GelRed ${ }^{\circledR}$ fluorescent dye and visualization under UV light. The resulting PCR products were sequenced by Genomed Joint-Stock Company, Warsaw, Poland. Sequences were then compared with identified reference sequences recorded in the database website GenBank [37]. The process resulted in the identification of the strain with the highest percent similarity with the query sequence.

\subsection{Data Analysis}

An analysis of the effects of the different foliar fertilisers on the abundances of VM, NM, and NV root tips was performed using Generalised Linear Mixed Models (GLMM) applied to a randomized complete block design with a binomial probability distribution. The Wald linear contrast was used in pairwise comparisons (as a post-hoc test) between different treatments. The GLMM model for the proportion of defined root types (mycorrhizal and non-mycorrhizal) is given by:

$$
p_{i k}=\theta+a_{i}+g_{k}+e_{i k}
$$

where $p_{i k}$ is the numerical proportion of specific root tips (mycorrhizal and non-mycorrhizal) for the $i$-th treatments in the $k$-th block and $\theta$ is the grand mean, $a_{i}$ the effect of the $i$-th treatment, $g_{k}$ the random effect of the $k$-th block and $e_{i k}$ the random effect of experimental error. 
To explore potential multivariate relationships among the abundances of VM, NM, and NV root tips in different study treatments, we used canonical correspondence analysis (CCA). We presented the results of the CCA using biplot figures. To assess the homogeneity of biometrical traits of seedlings used in this study, Linear Mixed Model for a randomized complete block design with random blocks was conducted. Shannon's diversity indices were calculated for the ECM assemblages of beech and oak seedlings. Statistical analyses were performed using R version 2.15.0 (The R Foundation for Statistical Computing, Vienna, Austria) [38] with the vegan package [39] for multivariate analysis (CCA). For the GLMM and LMM models we used the lme4 package. For means estimation and post-hoc test we used the lsmeans package in R. All statistical analyses were carried out separately for the two focal tree species. The accepted level of significance was $p<0.05$.

\section{Results}

\section{Growth of Seedlings and Mycorrhizal Colonization}

Our Linear Mixed Model analysis of the biometrical data of growth parameters of treated seedlings failed to reject the null hypothesis of no differences among treatments. Neither focal deciduous tree species exhibited differences by treatment in root collar diameter (LMM: $p=0.560, p=0.989$; overall means: $4.6 \mathrm{~mm}, 8.1 \mathrm{~mm}$; respectively, F. sylvatica and Q. robur), length of shoots (LMM: $p=0.188$, $p=0.848$; overall means: $22.8 \mathrm{~cm}, 66.2 \mathrm{~cm}$ ) or roots (LMM: $p=0.157, p=0.417$; overall means: $25.3 \mathrm{~cm}$, $34.7 \mathrm{~cm}$ ), or dry mass of shoots (LMM: $p=0.134, p=0.821$; overall means: $10.6 \mathrm{~g}, 10.1 \mathrm{~g}$ ), or roots (LMM: $p=0.906, p=0.861$; overall means: $14.1 \mathrm{~g}, 17.2 \mathrm{~g}$ ).

In all treatments, the rate of ECM colonization of F. sylvatica and Q. robur seedlings (expressed as the abundance of vital mycorrhizal root tips) was high and ranged from $55 \%$ for $F$. sylvatica seedlings treated with BF to $99 \%$ for F. sylvatica and Q. robur treated with Act (Table 1). In both tree species, the total number of NV root tips was significantly higher (GLM, $p<0.0001)$ in the EM treatment $(44.8 \%$ and $47.8 \%$, respectively, for F. sylvatica and Q. robur) than in the controls and in seedlings treated with Act and BF. Beech seedlings treated with BF exhibited a lower degree of mycorrhizal colonisation and a higher share of $\mathrm{NV}$ tips in comparison to the control and Act variant seedlings. Non-mycorrhizal (NM) root tips were not observed in F. sylvatica seedlings, whereas in Q. robur seedlings the highest abundance of NM root tips (8.1\%) was recorded in the control variant.

Table 1. Abundance (\%) of vital ECM (VM), non-vital (NV) and non-ECM (NM) root tips on 3-year-old Fagus sylvatica and Quercus robur seedlings after the first growing season in a bare-root nursery. Each experimental plant received one of the following treatments: Act-Actifos, BF-Busz Forte, EM-effective microorganisms and control (no treatment). Different lower-cased letters indicate significant differences among treatments (GLM, $p<0.0001)$.

\begin{tabular}{|c|c|c|c|c|c|c|c|c|c|c|c|c|c|c|c|c|}
\hline \multirow{4}{*}{$\begin{array}{c}\text { Indices } \\
\text { VM }\end{array}$} & \multicolumn{16}{|c|}{ Abundance (\%) } \\
\hline & \multicolumn{8}{|c|}{ Fagus sylvatica } & \multicolumn{8}{|c|}{ Quercus robur } \\
\hline & \multicolumn{2}{|c|}{ Control } & \multicolumn{2}{|c|}{ Act } & \multicolumn{2}{|c|}{ BF } & \multicolumn{2}{|c|}{ EM } & \multicolumn{2}{|c|}{ Control } & \multicolumn{2}{|c|}{ Act } & \multicolumn{2}{|c|}{ BF } & \multicolumn{2}{|c|}{ EM } \\
\hline & 99.4 & $\mathrm{a}$ & 99.2 & a & 83.3 & $\mathrm{~b}$ & 55.2 & c & 90.5 & $\mathrm{a}$ & 99.3 & $\mathrm{a}$ & 96.5 & $\mathrm{a}$ & 52.2 & $b$ \\
\hline NV & 0.6 & c & 0.8 & c & 16.6 & $\mathrm{~b}$ & 44.8 & $\mathrm{a}$ & 1.4 & $\mathrm{~b}$ & 0.7 & $\mathrm{~b}$ & 3.5 & $\mathrm{~b}$ & 47.8 & $\mathrm{a}$ \\
\hline NM & 0.0 & a & 0.0 & a & 0.0 & a & 0.0 & a & 8.1 & a & 0.0 & $\mathrm{~b}$ & 0.0 & $\mathrm{~b}$ & 0.0 & $b$ \\
\hline
\end{tabular}

In beech seedlings, ascomycete ECM were more abundant (61\%) than basiodiomycete ECM $(39 \%)$, while in oak seedlings the reverse was true, with 57\% basidiomycete ECM and $43 \%$ ascomycete ECM. The fungal DNA amplifications allowed for precise identification of the samples, with the exception of one morphotype, which was similar to Cenococcum (and thus hereafter referred to as Cenococcum-like). Seven ECM fungal taxa were found associated with F. sylvatica seedlings: The four most frequent taxa were shared among all treatments (Pezizaceae sp., Tuber maculatum, Cenococcum-like and Hebeloma sp.). One species (Peziza ostracoderma) was found exclusively in Act and BF treatments. 
Clavulina sp. was found only in controls and in BF-treated blocks, and Scleroderma areolatum was observed exclusively in Act treatments (Table 2). Seven taxa were also detected on $Q$. robur roots; four of these (P. ostracoderma, Tuber sp., Naucoria salicis and S. areolatum) were observed in all treatments and these fungi were the most frequent across $Q$. robur samples. One taxon (Cenococcum-like) was detected only in control and Act treatments, whereas another two (Inocybe curviceps and Laccaria tortilis) were observed in all treatments with the exception of seedlings treated with EM (Table 2). Three mycorrhizal taxa (Cenococcum-like, S. areolatum and P. ostracoderma) were shared between both tested tree species. The mean fungal species richness per seedling ranged from one to four on F. sylvatica roots, and from one to six on $Q$. robur roots. According to the Shannon diversity index $\left(\mathrm{H}^{\prime}\right)$ estimates, beech seedlings treated with EM had lower richness of mycorrhizal fungi (0.44) compared with BF treatment $(0.66)$. Oak seedlings in EM treatments showed the lowest richness of ECM fungi at 0.7 (Table 2). Pezizaceae sp. and Hebeloma sp. were the most common taxa and dominated the mycorrhizal fungal community on F. sylvatica seedlings, whereas P. ostracoderma and N. salicis were the most dominant on Q. robur roots.

Table 2. Molecular identification, relative abundance and frequency of fungal taxa (calculated as percent of mycorrhizal roots colonized/percent of colonized plants), total and mean species richness per seedling, and estimated species richness of ECM fungi observed on root tips of Fagus sylvatica and Quercus robur seedlings after one year of growth in a bare-root nursery. Experimental plants were each assigned to one of the following treatments: Act, BF, EM and control (no treatment).

\begin{tabular}{|c|c|c|c|c|c|c|c|c|c|c|}
\hline \multirow[b]{3}{*}{ Identification } & \multicolumn{2}{|c|}{ BLAST Top-Hit } & \multicolumn{8}{|c|}{ Relative Abundance/Frequency } \\
\hline & \multirow[b]{2}{*}{ Closest Match } & \multirow[b]{2}{*}{ NCBI } & \multicolumn{4}{|c|}{ Fagus sylvatica } & \multicolumn{4}{|c|}{ Quercus robur } \\
\hline & & & Control & Act & BF & EM & Control & Act & BF & EM \\
\hline \multicolumn{11}{|l|}{ Ascomycota } \\
\hline Pezizaceae sp. & Pezizaceae & MH040299 & $53 / 72$ & $85 / 100$ & $43.7 / 60$ & $0.9 / 8$ & & & & \\
\hline Peziza ostracoderma & Peziza sp. & MH040300 & & $5.2 / 24$ & $3.4 / 32$ & & $24 / 67$ & $6 / 33$ & $43.3 / 93$ & $20.4 / 67$ \\
\hline Tuber maculatum & Tuber maculatum & MH040280 & & & & & $16 / 67$ & $9.6 / 47$ & $7.3 / 67$ & $13.4 / 73$ \\
\hline Tuber sp. & Tuber sp. & MH040296 & $5.3 / 68$ & $6.5 / 44$ & $7.2 / 92$ & $6.2 / 100$ & & & & \\
\hline Cenococcum-like & Cenococcum geophilum & & $1.2 / 24$ & $0.2 / 16$ & $0.8 / 36$ & $4.2 / 28$ & $2.7 / 27$ & $7.8 / 27$ & & \\
\hline \multicolumn{11}{|l|}{ Basidiomycota } \\
\hline Hebeloma sp. & Hebeloma sacchariolens & MH040294 & $40.1 / 32$ & $3.2 / 44$ & $42.4 / 32$ & $88.8 / 32$ & & & & \\
\hline Naucoria salicis & Naucoria salicis & MH040281 & & & & & $28.5 / 93$ & $26 / 73$ & $16.8 / 67$ & $13.2 / 60$ \\
\hline Scleroderma areolatum & Scleroderma areolatum & MH040287 & & $0.04 / 4$ & & & $10.5 / 40$ & $8.6 / 47$ & $29 / 73$ & $11.1 / 40$ \\
\hline Laccaria tortilis & Laccaria tortilis & MH040289 & & & & & $3.4 / 27$ & $5.7 / 40$ & $4.3 / 53$ & \\
\hline Inocybe curviceps & Inocybe curviceps & MH040283 & & & & & $1.9 / 20$ & $36.2 / 87$ & $4.5 / 20$ & \\
\hline Clavulina sp. & Clavulina sp. & MH040298 & $0.4 / 4$ & & $2.5 / 4$ & & & & & \\
\hline \multicolumn{2}{|c|}{ Observed species richness } & & 5 & 6 & 6 & 4 & 7 & 7 & 6 & 4 \\
\hline \multicolumn{2}{|c|}{ Mean species richness per seedling } & & 4 & 4 & 4 & 3 & 6 & 5 & 6 & 3 \\
\hline \multicolumn{2}{|c|}{ Shannon diversity index $\left(\mathrm{H}^{\prime}\right)$} & & $0.55^{\mathrm{ab}}$ & $0.55^{\mathrm{ab}}$ & $0.66^{\mathrm{a}}$ & $0.44^{\mathrm{b}}$ & $1.03^{\mathrm{a}}$ & $1.11^{\mathrm{a}}$ & $1.04^{\mathrm{a}}$ & $0.70^{\mathrm{b}}$ \\
\hline
\end{tabular}

With regard to VM, NV, and NM root tips, the CCA indicated apparent correlations between NV tips and EM treatment in the case of F. sylvatica and non-treated (control) Q. robur seedlings (Figure 2).

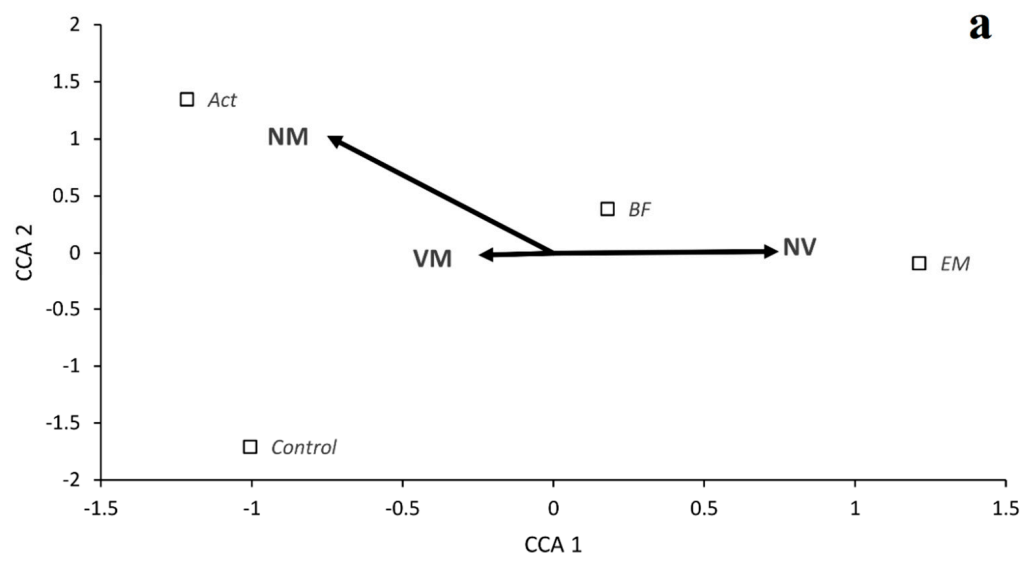

Figure 2. Cont. 


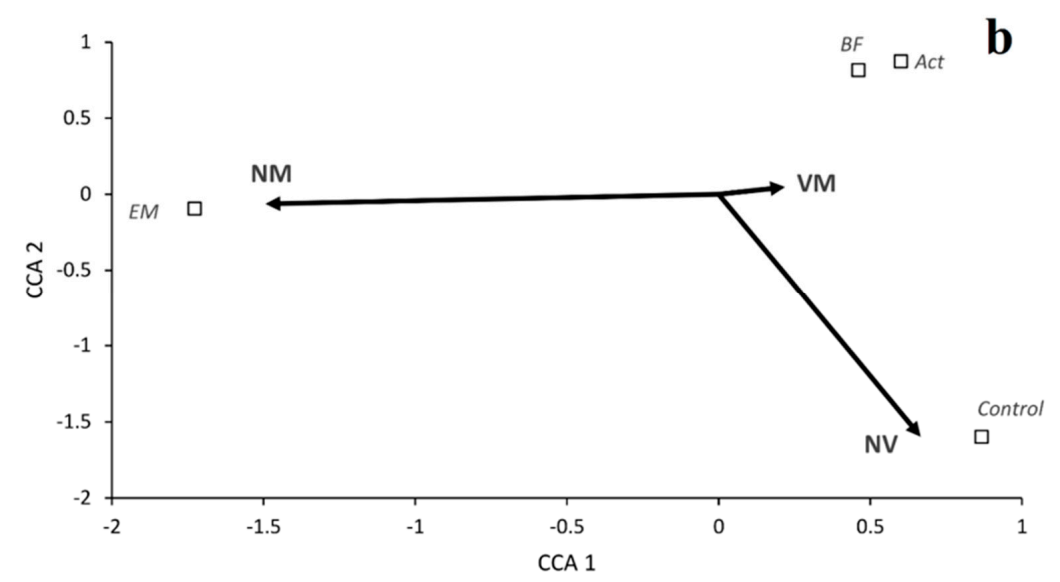

Figure 2. Canonical correspondence analysis (CCA) of the abundance of different root tips: VM, NM, and NM observed on Fagus sylvatica (a) and Quercus robur (b) seedlings by treatment: Act-Actifos, BF-Busz Forte, EM-effective microorganisms, and C—control seedlings without treatment.

\section{Discussion}

We observed no effect on the biometrical parameters on beech and oak seedlings from foliar application of (EM). Positive impacts of EM on woody plants had been demonstrated in previous studies. For example, greater plant growth, leaf number, and leaf area, fresh and dry plant weight, chlorophyll content and foliar nutrient content $(\mathrm{N}, \mathrm{K}$, and $\mathrm{P})$ were observed after foliar application of EM on Prunus dulcis seedlings for one season [40]. Khan et al. [41] observed a positive effect of EM on Albizia saman germination, and seedling growth in plants treated with different concentrations of EM solutions in a nursery experiment. EM treatments were reported to significantly increase the vegetative growth of Anna (cultivar) apple trees, as well as their leaf chlorophyll content and leaf mineral values (N, P, K, Fe, Zn, and Mn) compared with untreated trees [42]. Moreover, EM applications were reported to increase the quantity of soil microflora, based on density estimates of colony-forming units of total bacteria using soil extract agar medium, total fungi using rose-bengal streptomycin agar medium and total actinomycetes using Jensen's medium. According to Olle and Williams [43] 70\% of publications reported a positive effect of EM on vegetable growth. Moreover, Wididana and Higa [44] showed that foliar application of EM can increase the growth and yield of vegetable crops in a relatively short time. EM cultures applied in soil stimulate the decomposition of organic matter thereby realizing inorganic nutrients for plant uptake, while foliar-applied might to suppress the plant diseases and facilitates the up-take of simple organic molecules that can increase nutrition of plants. The mentioned authors stated that the mechanism of affection of EM on yield increase is not known. A commonly used method in the forestry of fertilizing is the installation of fertilizer at the sprinkler and the combination of irrigation and fertilization. Fertilizing in foliar form is also necessary in cases of periodic restriction of nutrient uptake by the roots [20]. According to Javaid [45] the foliar application of these microorganisms enhanced nodulation and yield of the test plant in NPK fertilizers and green manure amendments. Pati and Chandra [46] showed that foliar application of EM resulted in a large number of beneficial microorganisms at the leaf surface, or phyllosphere. They claim that certain microorganisms in the EM culture, including photosynthetic bacteria and $\mathrm{N}$-fixing bacteria, can enhance the plant's photosynthetic rate and efficiency, and its N-fixing capacity as well [46]. Górski and Kleiber [47] observed that foliar application of EM had a positive effect on the diameter of flowers in Rosa $\times$ hybrida. The results of all of these previous studies are in contrast with ours. However, Mayer et al. [48] found no differences in soil microbial parameters following treatments with EM compared with controls. The studies cited above focused on growth parameters and the nutrient status of the tested plants, while the status of mycorrhizal colonisation was omitted. It should be stressed that adequate ECM colonisation, in addition to classic quality criteria such as plant height, root collar diameter, shoot biomass, root system quality, absence of phytopathogenes, etc., is an important feature 
of forest nursery seedlings. The EM tested here are recommended, and proven in cultivation of fruit trees and crop plants, but did not have beneficial effects on the forest tree species examined here. It is possible that the lack of detected differences in biometrical parameters in this study could be due to age of the oak and beech seedlings. In a given nursery where the seedlings had an even dose of irrigation and fertilizers no difference in biometrics parameters might be observed. For example, Araujo et al. [49] observed the great differences of biometric parameters compering seedlings between different nurseries. However, differences in initial (pretreatment) size and mycorrhizal colonization of roots systems were not examined.

In our study, the abundance of VM root tips on beech and oak roots, except in the EM treatments, was very high, ranging from $83 \%$ to $99 \%$. This finding is in agreement with other studies on ECM associated with seedlings in forest nurseries [10,12]. The observed negative effect of BF on mycorrhizal colonisation of beech seedlings might be explained by allelopathy, as Busz Forte comprises herbal ingredients containing highly active biochemicals Allium sativum (which releases the organosulfur compound allicin from alliin). Castellano and Gorchov [50] found a negative influence of non-mycorrhizal herbaceous Alliaria petiolata (Garlic Mustard) on ECM colonisation of Q. rubra seedlings. In that case, ECM colonisation on oak roots was reduced near invasive Alliaria petiolata plants, as members of the Brassicaceae (mustard family) contain a diversity of secondary compounds, many of which deter herbivory [51] and have been shown to have an inhibitory effect on ECM fungi [52].

For both focal tree species, we observed seven taxa of ECM fungi associated with 3-year-old seedlings. This number of recognized taxa was smaller than found in previous studies of 2-year-old Quercus petraea and Q. robur seedlings (20 and 23 taxa, respectively) [10] but comparable with European beech previously grown in nursery conditions [12]. Pietras et al. [12] observed a species richness of ECM taxa ranging from six to 13 on beech roots, and each analysed nursery had a unique structure of ECM assemblages. In that study, Pietras et al. [12] stressed that the ECM fungal communities in forest bare-root nurseries are fairly diverse, and that the unique ECM community composition might be a result of specific cultivation practices and environmental factors. This concept is in line with our observations. Beech seedlings were dominated by Pezizaceae sp. and Hebeloma sp. mycorrhizae, whereas oaks were dominated by P. ostracoderma and N. salicis. The seedbed effect apparently influenced the ECM community composition. Peziza ostracoderma was preferentially associated with beech seedlings treated with Act and BF, while I. curviceps was much more abundant on oak roots in the Act-treated groups. In some species (P. ostracoderma, S. areolatum and Cenococcum-like), identical morphotypes were observed on both beech and oak roots, indicating that these fungi can colonise both host genera (Table 2).

In the current study, a significant and negative impact of EM on the proportion and on the diversity of vital ECM root tips was observed in both beech and oak seedlings, along with a strong increase in the proportion of non-vital root tips. We do not have a functional explanation of the mechanisms responsible for this result, nor do we have data on performance after outplanting of seedlings with increased proportion of non-vital root tips. However, ECM abundance, vitality, and diversity are probably key features influencing seedling establishment, since European beech and pedunculate oak are considered to be obligately associated with ECM fungi in the natural condition [7]. Some authors have argued that inoculating nursery seedlings with mycobionts holds promise for improving outplanting performance only if site-adapted fungi are used [53]. Therefore, a practical alternative is to improve nursery practices by using substances and microorganisms to enhance plant growth [54] and natural populations of mycorrhizal fungi. Seedlings growing in the nursery with diverse mycorrhizae may perform better than those growing with only one or a few nursery-adapted types [53]. The effect of EM on ectomycorrhizal structure after a long-term period may be positive; for example, Hu and Qui [55] and Khaliq et al. [56] found that long-term EM application in combination with organic and mineral nutrient sources enhanced wheat straw biomass, grain yields, and straw and grain nutrition. 
The tested mineral and organic fertilizers (Act and BF) were compatible with a high degree of ECM colonisation, despite a moderate increase in NV root tips in beech treated with BF, and did not have a negative impact on ECM diversity (Table 2). Fertilization management favours the conditioning of seedling stock through build-up of nutrient reserves in the seedling to boost performance following outplanting in the field [57].

To our knowledge, based on available literature, this is the first report examining the influence of EM on ECM colonisation and health status of roots of F. sylvatica and Q. robur seedlings in a bare-root nursery.

\section{Conclusions}

None of the tested products were phytotoxic to the experimental Q. robur and F. sylvatica seedlings. No significant effect on growth parameters was observed after the first year of application of experimental treatments. However, our results suggested that foliar application of EM may increase the proportion of non-vital root tips and negatively affect ECM diversity and the proportion of vital ECM root tips. Meanwhile, the effects of foliar application of mineral and organic fertilizers on ECM abundance and diversity were near neutral. Potential trade-offs between the positive effects of fertilization practices on seeding growth and conditioning, and the impacts of fertilization on ECM colonisation and diversity in bare-root forest merit further investigations.

Author Contributions: J.O., H.S., K.S., and D.H. generated the data. All authors analysed and discussed the data. The manuscript was written by R.M.B. Statistical analysis was performed using $\mathrm{R}$ version 2.15.0 (The $\mathrm{R}$ Foundation for Statistical Computing, Vienna, Austria) with the vegan package for multivariate analysis by M.S. The general conception of the project was provided by T.O.

Funding: This work was financed by the State Forest Holding in Poland through Project No. BLP 367 (contract number OR-2717/21/11) and Forest Research Institute (Project No. 260102).

Acknowledgments: All reviewers are acknowledged for their valuable comments and suggestions, which greatly improved the paper.

Conflicts of Interest: The authors declare no conflict of interest.

\section{References}

1. Fao.org. Available online: http://www.fao.org/ (accessed on 15 November 2017).

2. Payn, T.; Carnus, J.-M.; Freer-Smith, P.; Kimberley, M.; Kollert, W.; Liu, S.; Orazio, C.; Rodriguez, L.; Neves Silva, L.; Wingfield, M.J. Changes in planted forests and future global implications. For. Ecol. Manag. 2015, 352, 57-67. [CrossRef]

3. Central Statistical Office. Forestry 2017. Warsaw 2017. Available online: https://stat.gov.pl/en/topics/ agriculture-forestry / forestry / forestry-2017,1,8.html (accessed on 25 September 2018).

4. Central Statistical Office. Report on the Condition of Forests in Poland 2017. Warsaw 2017. Available online: http:/ / www.lasy.gov.pl/pl/informacje/publikacje/in-english/forests-in-poland/lasyw-polsce-2017-en.pdf (accessed on 25 September 2018).

5. Ducousso, A.; Bordacs, S. EUFORGEN Technical Guidelines for Genetic Conservation and Use for Pedunculate and Sessile oaks (Quercus robur and Q. petraea); International Plant Genetic Resources Institute: Rome, Italy, 2004.

6. Von Wuehlisch, G. EUFORGEN Technical Guidelines for Genetic Conservation and Use for European Beech (Fagus sylvatica); Bioversity International: Rome, Italy, 2008.

7. Wang, B.; Qiu, Y.L. Phylogenetic distribution and evolution of mycorrhizas in land plants. Myzorrhiza 2006, 16, 299-363. [CrossRef] [PubMed]

8. Kovacs, G.; Pausch, M.; Urban, A. Diversity of ectomycorrhizal morphotypes and oak decline. Phyton Ann. Rei Bot. A 2000, 40, 109-116.

9. Mosca, E.; Montecchio, L.; Sella, L.; Garbaye, J. Short-term effect of removing tree competition on the ectomycorrhizal status of a declining pedunculate oak forest (Quercus robur L.). For. Ecol. Manag. 2007, 244, 129-140. [CrossRef] 
10. Leski, T.; Pietras, M.; Rudawska, M. Ectomycorrhizal fungal communities of pedunculate and sessile oak seedlings from bare-root forest nurseries. Mycorrhiza 2010, 20, 179-190. [CrossRef] [PubMed]

11. Pena, R.; Offermann, C.; Simon, J.; Naumann, P.S.; Geßler, A.; Holst, J.; Dannenmann, M.; Mayer, H.; Kögel-Knabner, I.; Rennenberg, H.; et al. Girdling affects ectomycorrhizal fungal (EMF) diversity and reveals functional differences in EMF community composition in a beech forest. Appl. Environ. Microbiol. 2010, 76, 1831-1841. [CrossRef] [PubMed]

12. Pietras, M.; Rudawska, M.; Leski, T.; Karliński, L. Diversity of ectomycorrhizal fungus assemblages on nursery grown European beech seedlings. Ann. For. Sci. 2013, 70, 115-121. [CrossRef]

13. Pena, R.; Polle, A. Attributing functions to ectomycorrhizal fungal identities in assemblages for nitrogen acquisition under stress. ISME J. 2014, 8, 321-330. [CrossRef] [PubMed]

14. Leberecht, M.; Dannenmann, M.; Gschwendtner, S.; Bilela, S.; Meier, R.; Simon, J.; Rennenberg, H.; Schloter, M.; Polle, A. Ectomycorrhizal communities on the roots of two beech (Fagus sylvatica) populations from contrasting climates differ in nitrogen acquisition in a common environment. Appl. Environ. Microbiol. 2015, 81, 5957-5967. [CrossRef] [PubMed]

15. Brundrett, M.C. Coevolution of roots and mycorrhizas of land plants. New Phytol. 2002, 154, $275-304$. [CrossRef]

16. Smith, S.E.; Read, D.J. Mycorrhizal Symbiosis, 3rd ed.; Academic Press: Cambridge, UK, 2008.

17. Dahm, H.; Strzelczyk, E.; Cisielska, A.; Redlak, K. The effect of mycorrhizal fungi and bacteria on pine seedlings. Acta Mycol. 1988, 33, 25-36. [CrossRef]

18. Vaario, L.; Tervonen, A.; Haukioja, K.; Haukioja, M.; Pennanen, T.; Timonen, S. The effect of nursery substrate and fertilization on the growth and ectomycorrhizal status of containerized and outplanted seedlings of Picea abies. Can. J. For. Res. 2009, 39, 64-75. [CrossRef]

19. Sousa, N.R.; Franco, A.R.; Oliveira, R.S.; Castro, P.M.L. Ectomycorrhizal fungi as an alternative to the use of chemical fertilisers in nursery production of Pinus pinaster. J. Environ. Manag. 2012, 95, S269-S274. [CrossRef] [PubMed]

20. Wesoły, W.; Hauke, M. Szkótkarstwo Leśne od A do Z; CILP: Warszawa, Poland, 2009; pp. 118-254.

21. Walker, R.F. Growth and nutritional responses of containerized sugar and Jeffrey pine seedlings to controlled release fertilization and induced mycorrhization. For. Ecol. Manag. 2001, 149, 163-179. [CrossRef]

22. Rincón, A.; Parladé, J.; Pera, J. Influence of the fertilisation method in controlled ectomycorrhizal inoculation of two Mediterranean pines. Ann. For. Sci. 2007, 64, 577-583. [CrossRef]

23. Edmonds, R.L. General Strategies of Forest Disease Management. In Infectious Forest Diseases; Lilja, A., Poteri, M., Gonthier, P., Nicolotti, G., Eds.; CBA International: Wallingford, UK, 2013; pp. $29-49$.

24. Arnebrant, K. Nitrogen amendments reduce the growth of extramatical mycelium. Mycorrhiza 1994, 5, 7-15. [CrossRef]

25. Liu, Q.; Loganathan, P.; Hedley, M.J.; Grace, L.J. Effect of mycorrhizal inoculationon rhizosphere properties, phosphorus uptake and growth of pine seedlings treated with and without a phosphate rock fertilizer. J. Plant Nutr. 2008, 31, 137-156. [CrossRef]

26. Van Wambeke, E.; Van Assche, C.; Vanachter, A. Long term risks or benefits from soil fumigant use? Med. Fac. Landbouww. Univ. Gent. 1992, 57, 1261-1268.

27. Cordell, C.E.; Marx, D.H. Effects of nursery cultural practices on management of specific ectomycorrhizae on bareroot tree seedlings. In Mycorrhizas and Plant Health; Pfleger, F.L., Linderman, R.G., Eds.; APS Press: St-Paul, MN, USA, 1994; pp. 133-151.

28. Higa, T. Effective microorganisms: A biotechnology for mankind. In Proceedings of the First International Conference on Kyusei Nature Farming, Khon Kaen, Thailand, 17-21 October 1989; Parr, J.F., Hornick, S.B., Eds.; U.S. Department of Agriculture: Washington, DC, USA, 1991; pp. 8-14.

29. Higa, T.; Parr, J.F. Beneficial and Effective Microorganisms for a Sustainable Agriculture and Environment; International Nature Farming Research Center: Atami, Japan, 1994.

30. Curtis, H.; Noll, U.; Störmann, J.; Slusarenko, A.J. Broad-spectrum activity of the volatile phytoanticipin allicin in extracts of garlic (Allium sativum L.) against plant pathogenic bacteria, fungi and Oomycetes. Physiol. Mol. Plant Pathol. 2004, 65, 79-89. [CrossRef] 
31. Slusarenko, A.J.; Patel, A.; Portz, D. Control of plant diseases by natural products: Allicin from garlic as a case study. Eur. J. Plant Pathol. 2008, 121, 313-322. [CrossRef]

32. Higa, T. Effective microorganisms, concept and recent advances in technology. In Proceedings of the 4 th International Conference on Kyusei Nature Farming in Bellingham, Washington, DC, USA, 19-21 June 1995; Parr, J.F., Ed.; Department of Agriculture: Washingtod, DC, USA, 1998; pp. 247-248.

33. Montecchio, L.; Causin, R.; Rossi, S.; Mutto Accordi, S. Changes in ectomycorrhizal diversity in a declining Quercus ilex coastal forest. Phytopathol. Mediterr. 2004, 43, 26-34.

34. Agerer, R. Colour Atlas of Ectomycorrhizae, 1st-15th ed.; Einhorn: Munich, Germany, 1987-2008.

35. Agerer, R.; Rambold, G. DEEMY-An Information System for Characterization and Determination of Ectomycorrhizae, 2004-2015. Available online: http:/ / www.deemy.de (accessed on 12 December 2015).

36. Thermofisher.com. Available online: https://www.thermofisher.com/ (accessed on 15 November 2017).

37. Ncbi.nlm.nih.gov. Available online: http:/ / www.ncbi.nlm.nih.gov/ (accessed on 15 November 2017).

38. R Core Team. R: A Language and Environment for Statistical Computing; R Foundation for Statistical Computing: Vienna, Austria, 2012.

39. Oksanen, J.; Blanchet, F.G.; Kindt, R.; Legendre, P.; Minchin, P.R.; O’hara, R.B. Vegan: Community Ecology Package. R Package Version 2.4-2. Available online: https:/ / cran.r-project.org/web/packages/vegan/index. html (accessed on 24 August 2017).

40. Shokouhian, A.A.; Davarynejad, G.H.; Tehranifar, A.; Imani, A.; Rasoulzadeh, A. Investigation of Effective Microorganisms (EM) impact in water stress condition on growth of almond (Prunus dulcis mill) seedling. J. Basic. Appl. Sci. Res. 2013, 3, 86-92.

41. Khan, B.M.; Hossain, M.K.; Mridha, M.A.U. Effect of microbial inoculants on Albizia saman germination and seedling growth. J. For. Res. 2007, 17, 99-102. [CrossRef]

42. Mohamed, F.; Sahain, M.; Elham, Z.; Motty, A.; Mohamed, H.; Shiekh, El.; Laila, F. Effect of some biostimulant on growth and fruiting of Anna apple trees in newly reclaimed areas. Res. J. Agric. Biol. Sci. 2007, 3, 422-429.

43. Olle, M.; Williams, I.H. Effective microorganisms and their influence on vegetable production-A review. J. Hortic. Sci. Biotechnol. 2015, 88, 380-386. [CrossRef]

44. Higa, T.; Wididana, G.N. The concept and theories of effective microorganisms. In Proceedings of the First International Conference on Kyusei Nature Farming, Khon Kaen, Tailand, 17-21 October 1989; Parr, J.F., Hornick, S.B., Whitman, C.E., Eds.; Department of Agriculture: Washington, DC, USA, 1991; pp. 118-124.

45. Javaid, A. Foliar application of effective microorganisms on pea as an alternative fertilizer. Agron. Sustain. Dev. 2006, 26, 257-262. [CrossRef]

46. Pati, B.R.; Chandra, A.K. Effect of spraying nitrogen fixing phyllospheric bacterial isolates on wheat plants. Plant Soil 1981, 61, 419-427. [CrossRef]

47. Górski, R.; Kleiber, T. Effect of Effective Microorganisms (EM) on nutrient contents in substrate and development and yielding of Rose (Rosa $x$ hybrida) and Gerbera (Gerbera jamesonii). Ecol. Chem. Eng. S 2010, 17, 505-513.

48. Mayera, J.; Scheida, S.; Widmera, F.; Fliessbach, A.; Oberholzer, H.R. How effective are effective microorganisms (EM)? Results from a field study in temperate climate. Appl. Soil Ecol. 2010, 46, 230-239.

49. Araújo, G.C.; Sousa, N.R.; Ramos, M.; Vega, A.; Castro, P.M.L. Performance of Quercus suber L. at nursery stage-Application of two bio-inoculants under two distinct environments. Ann. For. Sci. 2018, 75. [CrossRef]

50. Castellano, S.M.; Gorchov, D.L. Reduced ectomycorrhizae on oak near invasive garlic mustard. Northeast. Nat. 2012, 19, 1-24. [CrossRef]

51. Fahey, J.W.; Zalcmann, A.T.; Talalay, P. The chemical diversity and distribution of glucosinolates and isothiocyanates among plants. Phytochemistry 2001, 56, 5-51. [CrossRef]

52. Wolfe, B.E.; Rodgers, V.L.; Stinson, K.A.; Pringle, A. The invasive plant Alliaria petiolata (Garlic Mustard) inhibits ectomycorrhizal fungi in its introduced range. J. Ecol. 2008, 96, 777-783. [CrossRef]

53. Perry, D.A.; Molina, R.; Amaranthus, M.P. Mycorrhizae, mycorrhizospheres and reforestation: Current knowledge and research needs. Can. J. For. Res. 1987, 17, 929-940. [CrossRef]

54. Calvo, P.; Nelson, L.; Kloepper, J.W. Agricultural uses of plant biostimulants. Plant Soil 2014, 383, 3-41. [CrossRef] 
55. Hu, C.; Qi, Y. Long-term effective microorganisms application promote growth and increase yields and nutrition of wheat in China. Eur. J. Agron. 2013, 46, 3-67. [CrossRef]

56. Khaliq, A.; Kaleem Abbasi, M.; Hussain, T. Effects of integrated use of organic and inorganic nutrient sources with effective microorganisms (EM) on seed cotton yield in Pakistan. Bioresour. Technol. 2006, 97, 967-972. [CrossRef] [PubMed]

57. Quoreshi, A.M. Nutritional preconditioning and ectomycorrhizal formation of Picea mariana (Mill.) B.S.P. seedlings. Eurasian J. For. Res. 2003, 6, 1-63.

(C) 2018 by the authors. Licensee MDPI, Basel, Switzerland. This article is an open access article distributed under the terms and conditions of the Creative Commons Attribution (CC BY) license (http:/ / creativecommons.org/licenses/by/4.0/). 